F. Reprod. Fert. (1966) 12, 23-31

REVIEW

\title{
ASSAYS OF HUMAN CHORIONIC GONADOTROPHIN IN RELATION TO CLINICAL PRACTICE
}

\author{
JOHN A. LORAINE \\ Medical Research Council Clinical Endocrinology Research Unit, \\ University of Edinburgh
}

\begin{abstract}
Summary. Suitable biological methods for the estimation of human chorionic gonadotrophin (HCG) in body fluids include those involving ovarian hyperaemia and prostatic weight in rats. Immunological assays depending on haemagglutination-inhibition and complementfixation tests lack specificity and cannot be recommended for the quantitative determination of the hormone.

In normal pregnancy HCG levels are high in the first trimester and much lower in the second and third trimesters. HCG activity appears in urine shortly after conception and disappears rapidly following delivery.

In patients with hydatidiform mole HCG levels in body fluids are generally but not invariably well above the normal range. Following surgical treatment of mole and of trophoblastic tumours of the uterus HCG assays may be a valuable guide to prognosis.

HGG readings in blood and urine are often abnormally high in women with severe pre-eclamptic toxaemia. In mild and moderate toxaemia levels are generally within the normal range.

Patients with hyperemesis gravidarum usually fail to show the peak period of HCG excretion in early pregnancy. HCG readings in such cases bear no definite relationship to the duration and severity of the vomiting.

In diabetic pregnancy and in threatened and habitual abortion assays of HCG are of little diagnostic or prognostic value. The administration of stilboestrol to pregnant diabetics causes a transient fall in HCG output.
\end{abstract}

\section{INTRODUCTION}

The year 1927 will always be remembered by endocrinologists for the epochmaking discovery of Aschheim \& Zondek (1927) that the blood and urine of pregnant women contained a substance which, when administered subcutaneously to intact immature mice, produced follicular maturation, luteinization and haemorrhage in the ovarian stroma. This substance which is now termed human chorionic gonadotrophin (HCG) is elaborated by the Langhans cells of chorionic villi of the human placenta and the evidence indicating that the placenta is the sole source of production of HGG during pregnancy has been summarized by Diczfalusy \& Troen (1961). 
HCG is predominantly luteinizing in action thus resembling pituitary luteinizing hormone in its biological properties. The most detailed studies of the chemical nature of HCG are those of Got (1959). This investigator extracted the hormone from pregnancy urine by chromatography on Dowex-2 and obtained a preparation the potency of which ranged from 10,000 to $12,000 \mathrm{i} . \mathrm{u} . / \mathrm{mg}$. The molecular weight of the hormone was estimated to be 30,000 ; its iso-electric point was at $\mathrm{pH} 2.95$ and the material was shown to be rich in carbohydrate mainly in the form of glucose and galactose. The first international standard for HCG was established in 1939, one i.u. being defined as the activity present in $0.1 \mathrm{mg}$ of the standard preparation; a second international standard for the hormone has recently become available. As emphasized by numerous investigators including Loraine (1950a, 1957) and Diczfalusy (1953) results of all assays of HCG should always be expressed in international units and not in arbitrary 'animal units'.

The present paper deals with two main topics. The first concerns methods

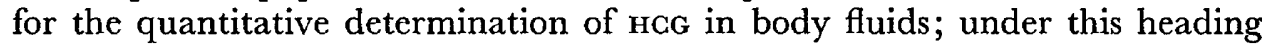
both biological and immunological procedures will be considered. The second describes the clinical application of HGG assays in serum and urine in normal and pathological conditions. Much of the subject-matter discussed in this paper has been recently reviewed by Loraine \& Bell (1966) to whose book the reader is referred for more detailed information. The estimation of HCG in relation to pregnancy diagnosis is described elsewhere in this volume and is not considered herein.

\section{Biological methods}

\section{METHODS OF ASSAY OF HCG}

Such assays are very numerous and for reviews on this subject articles by Emmens (1939), Loraine (1952, 1956) and Diczfalusy (1954) should be consulted. Of the very large number of techniques described in the literature only three will be briefly discussed.

Test depending on ovarian hyperaemia in rats. This method which was introduced by Zondek, Sulman \& Black (1945) as a pregnancy diagnosis test, has been used for quantitative assays of HCG in body fluids by various investigators including Albert \& Berkson (1951) and Borth, Lunenfeld \& de Watteville (1957, 1958). The chief advantage of the technique is its short duration, the total time required for its performance being only $4 \mathrm{hr}$. Its main disadvantages are its dependence on the strain of rat used (see Loraine \& Bell, 1966) and the fact that when assays are conducted on serum, the concentration of the latter is important, valid results being obtained only if serum is diluted prior to injection (Albert \& Berkson, 1951; Borth et al., 1957).

Tests depending on expulsion of spermatozoa in amphibia. In these procedures many species of amphibia have been used including Bufo arenarum (Galli-Mainini, 1947), Bufo bufo (Thorborg \& Hansen, 1951) and Xenopus laevis (Hobson, 1952). Such tests have proved of considerable value in relation to pregnancy diagnosis but have been less suitable for quantitative assays of HCG in blood and urine. Their main advantages are their simplicity and rapidity together with the fact that the same animal can be used repeatedly. Their main disadvantages 
include their relatively high degree of insensitivity, pronounced seasonal variations in the test animals employed and the necessity for using large numbers of animals for individual estimations because the assay depends on a quantal rather than a graded response.

Test depending on prostatic weight in rats. This procedure (Loraine, 1950a) which has been in operation in Edinburgh since 1948, is suitable for quantitative assays of HCG in urine, serum and placentae. Its main advantages are its high degree of precision and the fact that unextracted urine can be administered to the animals because the oestrogens present do not interfere with the response. Its main disadvantage is the fact that it is less rapid in its performance than the two methods described previously.

\section{Immunological methods}

Such techniques, the characteristics of which have recently been reviewed by Berson \& Yalow (1964), were originally developed as pregnancy diagnosis tests. Subsequently various investigators attempted to adapt them for quantitative assays of HCG in body fluids. Three types of procedure have been used and will be briefly considered.

Haemagglutination-inhibition tests. A typical example in this group is the method of Wide \& Gemzell (1960); this depends on the ability of a standard or test preparation of HCG to inhibit the agglutination reaction between HCG-coated sheep red blood cells and an antiserum to HGG produced in rabbits. The main advantages of the test are its high sensitivity, its rapidity and its low cost. The chief disadvantage is its relative lack of specificity. Test kits for methods similar in principle to that of Wide \& Gemzell (1960) have been marketed by Messrs Organon Ltd ('Pregnosticon') and by Burroughs Wellcome \& Co. Ltd ('Prepuerin'). Such techniques have proved valuable in the field of pregnancy diagnosis but are unsuitable for quantitative assays of HCG.

Complement-fxation tests. These were first applied to the assay of HCG by Brody \& Carlström $(1960,1961)$. The advantages and limitations of such methods are similar to those described above for haemagglutination-inhibition tests.

Radio-immunological assay. An assay method for HCG similar in principle to that of Hales \& Randle (1963) for insulin has recently been proposed by Wilde, Orr \& Bagshawe (1965). The procedure is claimed by its originators to be highly sensitive and to be capable of detecting as little as 0.06 i.u. of $\mathrm{HCG} / \mathrm{ml}$. The application of the technique to clinical problems will be awaited with interest.

\section{Comparison of bio-assays and immunological assays for $\mathrm{HCG}$}

Such comparisons have been made by Hobson \& Wide (1964) and by Borth, Ferin \& Menzi (1965). Hobson \& Wide (1964) who performed parallel assays in urine with the rat seminal vesicle method (see Loraine, 1950a) and a haemagglutination-inhibition test, found that during the second half of pregnancy results obtained by immuno-assay were considerably higher than those obtained by bio-assay. They also noted that methods used to concentrate the urine, e.g. acetone precipitation and kaolin adsorption, were capable of affecting the ratio of biological to immunological activity of HCG. 
Borth et al. (1965) recently reviewed results reported from a number of laboratories in which comparisons of bio-assays and immunological assays for HCG had been undertaken on the same urine samples. They found considerable divergence in the figures obtained by the two methods and concluded that the correlation was not sufficiently close to justify the replacement of biological by immunological procedures for the quantitative determination of $\mathrm{HCG}$ in body fluids.

\section{HCG ASSAYS IN NORMAL PREGNANGY}

\section{Results obtained by bio-assay}

The urinary excretion and serum concentration of HCG throughout normal pregnancy have been estimated by numerous investigators including Jones, Gey \& Gey (1944), Loraine (1950a), Albert \& Berkson (1951) and Fairweather \& Loraine (1962). It is agreed that during the first trimester from the 50 th to the 70th day of pregnancy, HCG is present in body fluids in very large quantities which are generally in the range, 20,000 to 100,000 i.u. per $24 \mathrm{hr}$ urine sample or per litre of serum. By the 10th week of pregnancy the so-called 'peak period' has passed and in the second and third trimesters HCG levels in blood and urine are much lower and much less variable than in early pregnancy. Loraine (1950a, 1957), using the prostatic weight method in assay in rats, found that from the 12th week of pregnancy onwards to term HGG readings in serum and urine were in the range 4000 to 11,000 i.u. $(P=0.99)$ and suggested that in individual subjects levels consistently outside these limits might be regarded as pathological. The renal clearance of HCG during normal pregnancy has been studied by Gastineau, Albert \& Randall (1949) and by Loraine $(1950 \mathrm{~b})$. Values remain relatively constant throughout the gestation period but are low, being generally less than $1 \mathrm{ml} / \mathrm{min}$.

HCG appears in body fluids very shortly after conception. Jones, Delfs \& Stran (1944) detected the presence of the hormone in serum 12 days following the date on which it was believed that conception had occurred, while Riley (1959) reported HCG activity in serum 16 days after conception. Brown, Klopper \& Loraine (1958) studied hormone excretion patterns in a woman who delivered a female child following a successful artificial insemination. They noted a marked rise in urinary gonadotrophin levels, probably due to the presence of $\mathrm{HCG}, 9$ days following the insemination.

The most detailed investigation into the disappearance rate of HCG from urine following parturition is that of Allison (1960) who, using the assay method depending on spermiation in the male toad Bufo bufo, studied 2808 subjects. In $94 \%$ of the women urinary HCG could not be detected when assays were performed on the 6 th, 7 th and 8 th days after parturition and in only $1.2 \%$ of the subjects was activity found by the 10th day following delivery.

\section{Results obtained by immunological assay}

Haemagglutination-inhibition tests have been used to estimate HCG levels in serum and urine throughout normal pregnancy by Gemzell and his collaborators (Wide \& Gemzell, 1960; Wide, 1962; Mishell, Wide \& Gemzell, 1963) and by McCarthy, Pennington \& Crawford (1964), while complement- 
fixation tests in serum only have been performed by Brody \& Carlström (1962). Although the pattern of HCG readings reported by immunological methods is roughly similar to that found by bio-assay the average figures obtained by the former group of techniques at all stages of pregnancy are considerably higher than those obtained by the latter. This observation suggests that results reported by immunological assay represent an overestimate of true biological potency and are probably of little quantitative significance.

\section{HCG ASSAYS IN PATHOLOGICAL CONDITIONS}

\section{Hydatidiform mole}

One of the most detailed early studies was that of Hamburger (1944) who conducted HCG assays in twenty patients with hydatidiform mole. He found very variable levels ranging from 6000 to $20,000,000$ i.u./l of urine. In the majority but not in all of the patients HGG readings were above the range encountered in normally pregnant women; however, a considerable degree of overlap existed between the two groups of subjects. Hamburger's conclusion regarding the diagnostic value of HCG estimations in hydatidiform mole was that such assays were of limited use only, providing information which was suggestive but not definitely diagnostic of the condition. This conclusion remains valid more than two decades later.

In uncomplicated cases of hydatidiform mole Hamburger (1944), Hobson $(1955,1958)$ and others have shown that complete evacuation of the mole causes a rapid disappearance of urinary HGG activity and that in the majority of subjects so treated the hormone cannot be detected in urine 3 months after surgical intervention. As demonstrated by Hamburger (1944) and by Delfs (1959) the pattern of HCG excretion is markedly different in patients in whom complications such as retained molar fragments of choriocarcinoma of the uterus occur. Under such circumstances serial assays of urinary HCG may be of considerable diagnostic and prognostic value, levels remaining high or tending to rise following surgical treatment of the mole.

\section{Trophoblastic tumours of the uterus}

HCG assays in such tumours have been performed by various investigators including Hertz and his associates (Li, Hertz \& Bergenstal, 1958; Hertz, Bergenstal, Lipsett, Price \& Hilbish, 1958), Hobson (1959), Bagshawe \& Wilde (1965) and Bagshawe (1965). Levels of HCG in patients with choriocarcinoma of the uterus are generally in the same range as in hydatidiform mole and the two conditions cannot be differentiated by such estimations (see Loraine \& Bell, 1966).

Hobson (1959) has reported results of urinary HCG assays in patients with chorio-adenoma destruens and choriocarcinoma. He found that before hysterectomy readings in subjects with both types of tumour were in the same range as in normally pregnant women during the first trimester. Following operation, women with choriocarcinoma continued to excrete large amounts of HGG until death; on the other hand, in patients with chorio-adenoma destruens activity could not be detected in urine some 4 weeks after surgery.

The prognostic value of urinary HCG assays in patients with choriocarcinoma 
and related trophoblastic tumours, treated with the folic acid antagonist 4-amino $\mathrm{N}^{10}$ methyl pteroylglutamic acid (Methotrexate), has been investigated by Li et al. (1958) and by Hertz et al. (1958). They found that in women responding well to this form of treatment a marked fall in HCG output occurred and that excretion values remained low while the disease was in remission. On the other hand, an exacerbation of the condition was usually associated with a rise in urinary HCG levels.

\section{Choriocarcinoma of the testis}

This type of neoplasm is invariably associated with high HCG levels in body fluids (see Twombly, 1944; Hamburger, 1946). According to Ferguson (1933) and Furuhjelm (1940), men with choriocarcinoma of the testis may excrete quantities of the hormone similar to those found in cases of hydatidiform mole. Hobson (1965) states that urinary HCG levels in such patients can range from 3000 to $2,000,000$ i.u./l.

\section{Threatened and habitual abortion}

A careful study of serum HCG readings in patients with a history of habitual abortion was made by Delfs \& Jones in 1948. They found that in women in whom the foetus was abnormal or who showed evidence of a poorly functioning trophoblast HCG levels were generally, but not invariably, below the normal range for the corresponding stage of pregnancy.

Hughes, Loraine, Bell \& Layton (1964) estimated urinary HCG together with oestrogens and pregnanediol in early pregnancy in women with previous histories of threatened and habitual abortion. No definite relationship could be demonstrated between the HCG levels on the one hand and the eventual outcome of the pregnancy on the other. In the opinion of Hughes et al. (1964) HCG assays in urine are of little or no value in the management of patients with these conditions.

\section{Pre-eclamptic toxaemia}

In severe pre-eclamptic toxaemia Loraine \& Matthew (1950) showed that the mean urinary excretion and serum concentration of HCG was significantly higher than in normal pregnancy. However, in patients with moderate and mild toxaemia such a difference was not observed. No correlation could be demonstrated between the HCG levels and any clinical feature of the disease such as the degree of albuminuria or oedema or the height of the blood pressure.

Zondek \& Zondek (1965) have calculated the number of Leydig cells in the foetal and neonatal testis in normal and toxaemic pregnancy. They noted that the average number of cells was significantly higher in the toxaemic than in the control series, and suggested that this difference might be due to the raised HCG levels known to occur in a proportion of patients in the former group. This interesting suggestion requires further study.

\section{Hyperemesis gravidarum}

The most detailed recent study of urinary HGG levels in hyperemesis gravidarum is that of Fairweather \& Loraine (1962) who conducted assays in 
ninety such patients. They found that the peak period of HCG excretion which normally occurs in the first trimester of pregnancy was generally absent in hyperemesis, readings tending to remain relatively constant throughout the gestation period. No correlation could be demonstrated between the HCG readings and the frequency or severity of the vomiting.

\section{Diabetic pregnancy}

Some years ago White and her collaborators (White \& Hunt, 1943; White, 1952) stated that serum HCG assays might be useful in the management of pregnant diabetics by indicating which patients were likely to develop obstetric complications later in pregnancy. Unfortunately, the assay methods used by these investigators were unreliable, and it is now generally accepted that their conclusions were incorrect and that estimations of HCG in body fluids are of little or no prognostic value in patients with this condition (see Loraine \& Matthew, 1954).

Loraine (1949) studied the effect of the synthetic oestrogen stilboestrol, given by the oral route, on urinary HCG excretion in normal and diabetic pregnancy. He noted an initial reduction in output on commencement of therapy. However, this fall was transient in character and, in spite of continued administration of the drug, readings began to rise and eventually returned to their original levels. The effect of stilboestrol on placental function, as judged by HCG assays, is therefore different from its action on pituitary gonadotrophic activity since it has been demonstrated by Smith \& Albert (1955), Loraine \& Bell (1965) and others that throughout the period of administration of the compound, levels of pituitary gonadotrophins in urine remain low or undetectable.

\section{Rhesus pregnancy}

HCG assays by both biological and immunological methods have been reported in rhesus pregnancy (Zilliacus, Widholm \& Pesonen, 1954; McCarthy \& Pennington, 1964; Connon, 1964). Results obtained have been variable except for the finding that in late pregnancy the presence of a hydropic foetus is associated with abnormally high readings in blood and urine. In the absence of this complication levels of HGG in the body fluids of rhesus patients are generally within the normal range for the appropriate stage of gestation.

\section{REFERENCES}

Albert, A. \& Berkson, J. (1951) A clinical bio-assay for chorionic gonadotrophin. F. clin. Endocr. Metab. 11, 805.

Allison, R. M. (1960) The evaluation of urinary chorionic gonadotrophin in all post-gestational patients in the Huddersfield area for a period of one year. 7. Obstet. Gynaec. Br. Emp. 67, 632.

Aschнeim, S. \& Zondek, B. (1927) Hypophysenvorderlappenhormon und Ovarialhormon im Harn von Schwangeren. Klin. Wschr. 6, 1322.

Bagshawe, K. D. (1965) The therapy of trophoblastic neoplasia. The Early Conceptus, Normal and Abnormal, p. 135. Ed. W. W. Park. University of St Andrews Press.

BAGSHAwE, K. D. \& WILDE, C. E. (1965) Some aspects of the excretion of gonadotrophic hormones by patients with trophoblastic tumours. F. Obstet. Gynaec. Br. Commonw. 72, 59.

Berson, S. A. \& Yalow, R. S. (1964) Immunoassay of protein hormones. The Hormones, vol. 4, p. 615. Eds. G. Pincus, K. V. Thimann and E. B. Astwood. Academic Press, New York.

Borth, R., Ferin, M. \& Menzi, A. (1965) Comparison of bio-assay and immunossay of human chorionic gonadotrophin in urine. Acta endocr., Copenh. 50, 335. 
Borth, R., Lunenfeld, B. \& DE WATteville, H. (1957) Effect of serum used as vehicle on the quantal assay of human chorionic gonadotrophin by the ovarian hyperaemia response in rats. Acta endocr., Copenh. 24, 119.

Borth, R., Lunenfeld, B. \& DE WATTEville, H. (1958) Lack of diurnal variation of chorionic gonadotrophin levels in pregnancy serum. Acta endocr., Copenh. 29, 531 .

BROdy, S. \& CARLSTRÖM, G. (1960) Estimation of human chorionic gonadotrophin in biological fluids by complement fixation. Lancet, ii, 99.

Brody, S. \& Carlström, G. (1961) Clinical application of a serological method for the determination of human chorionic gonadotrophin. Nature, Lond. 189, 841.

BRody, S. \& CARLSTRÖM, G. (1962) Immuno-assay of human chorionic gonadotrophin in normal and pathologic pregnancy. F. clin. Endocr. Metab. 22, 564.

Brown, J. B., KLOPPER, A. \& LoRAine, J. A. (1958) The urinary excretion of oestrogens, pregnanediol and gonadotrophins during the menstrual cycle. F. Endocr. 17, 401.

Connon, A. F. (1964) Immunological assay of human chorionic gonadotrophin in rhesus-sensitised women, Lancet, i, 747.

Delfs, E. (1959) Chorionic gonadotrophin determinations in patients with hydatidiform mole and choriocarcinoma. Ann. N.Y. Acad. Sci. 80, 125.

Delfs, E. \& Jones, G. E. S. (1948) Endocrine patterns in abortion. Obstet. gynec. Surv. 3, 680.

Diczfalusy, E. (1953) Chorionic gonadotrophin and oestrogens in the human placenta. Acta endocr., Copenh. Suppl. 12.

DiczFalusy, E. (1954) An improved method for the bio-assay of chorionic gonadotrophin. Acta endocr., Copenh. 17, 58.

Diczfalusy, E. \& Troen, P. (1961) Endocrine functions of the human placenta. Vitams Horm. 19, 229.

EMmENs, C. W. (1939) Analysis of assays carried out in various laboratories on contributions offered towards international standard preparation of gonadotrophic substance of urine of pregnancy. Bull. Hlth Org. 8, 863.

FaIRWEATHer, D. V. I. \& LoRAine, J. A. (1962) Urinary excretion of human chorionic gonadotrophin in patients with hyperemesis gravidarum. Br. med. $7 . \mathbf{i}, 666$.

Ferguson, R. S. (1933) Quantitative behaviour of Prolan A in teratoma testis. Am. F. Cancer, 18, 269.

FURUhJelm, M. (1940) On excretion of oestrogenic and androgenic substances in urine of women; investigation covering 14 healthy women, 10 cases of myoma and 2 of castration. Acta obstet. gynec. scand. 20, Suppl. 1, 1.

Galli-Mainini, C. (1947) Reacción diagnóstica del embarazo en la que se usa el sapo macho como animal. Semana méd., B. Aires, 1, 337.

Gastineau, C. F., Albert, A. \& Randall, L. M. (1949) The renal clearance of chorionic gonadotrophic hormone in pregnancy, in neoplasm of the testis and in hydatidiform mole. 7 . clin. Endocr. Metab. 9, 615.

Got, R. (1959) Gonadotrophine choriale humaine. Isolement et caractérisation. Thèse de Sciences Société Saint Quentinoise d'Imprimerie, Paris.

Hales, C. N. \& Randee, P. J. (1963) Immunoassay of insulin with insulin-antibody precipitate. Biochem. 7. $88,137$.

Hamburger, C. (1944) Contribution to the hormonal diagnosis of hydatidiform mole and chorionepithelioma, based on 76 cases with hormonal analysis. Acta obstet. gynec. scand. 24, 45.

HAMBURGER, C. (1946) Gonadotrophins and sex hormones in cases of malignant tumours of the testis. 7. Endocr. 5, xxiv.

Hertz, R., Bergenstal, D. M., Lipsett, M. B., Price, E. B. \& Hilbish, T. F. (1958) Chemotherapy of choriocarcinoma and related trophoblastic tumors in women. $\mathcal{F}$. Am. med. Ass. 168, 845.

Hobson, B. M. (1952) Conditions modifying the release of spermatozoa in male Xenopus laevis in response to chorionic gonadotrophin. Q. Fl exp. Physiol. 37, 191.

Hobson, B. M. (1955) The excretion of chorionic gonadotrophin in normal pregnancy and in women with hydatidiform mole. 7. Obstet. Gynaec. Br. Emp. 62, 354.

Hosson, B. M. (1958) Further observations on the excretion of chorionic gonadotrophin by women with hydatidiform mole. F. Obstet. Gynaec. Br. Emp. 65, 253.

Hosson, B. M. (1959) The excretion of chorionic gonadotrophin by women with chorioadenoma and choriocarcinoma. 7. Obstet. Gynaec. Br. Emp. 66, 282.

Hobson, B. M. (1965) The hormone production of normal and abnormal trophoblast. The Early Conceptus, Normal and Abnormal, p. 121. Ed. W. W. Park. University of St Andrews Press.

Hobson, B. M. \& WIDE, L. (1964) The immunological and biological activity of human chorionic gonadotrophin in urine. Acta endocr., Copenh. 46, 632.

Hughes, H. E., Loraine, J. A., Belz, E. T. \& Layton, R. (1964) Cytological observations, cervical mucus 'ferning' and hormone assays in early pregnancy. Am. F. Obstet. Gynec. 90, 1297. 
Jones, G. E. S., DeLfs, E. \& Stran, H. M. (1944) Chorionic gonadotropin and pregnanediol values in normal pregnancy. Bull. Johns Hopkins Hosp. 75, 359.

Jones, G. E. S., Gey, G. O. \& Gey, M. K. (1944) Hormone production by placental cells maintained in continuous culture. Bull. Fohns Hopkins Hosp. 72, 26.

Li, M. C., Hertz, R. \& Bergenstal, D. M. (1958) Therapy of choriocarcinoma and related trophoblastic tumors with folic acid and purine antagonists. New Engl. F. Med. 259, 66.

Loraine, J. A. (1949) Excretion of chorionic gonadotrophin by pregnant diabetics. Br. med. F. ii, 1496.

Loraine, J. A. (1950a) The estimation of chorionic gonadotrophin in the urine of pregnant women. $\mathcal{F}$. Endocr. 6, 319.

LoRAine, J. A. (1950b) The renal clearance of chorionic gonadotrophin in normal and pathological pregnancy. Q. 7 l exp. Physiol. 36, 11.

LoRAINe, J. A. (1952) Recent developments in the clinical application of hormone assay. 7. Obstet. Gynaec. Br. Emp. 59, 535.

LORAINE, J. A. (1956) Bio-assay of pituitary and placental gonadotrophins in relation to clinical problems in man. Vitams Horm. 14, 305.

LORAINE, J. A. (1957) Some general principles in the bio-assay of anterior pituitary and placental hormones in blood with special reference to clinical problems. Ciba Foundation Colloquia on Endocrinology, Vol. 11, p. 19. Churchill, London.

LORAINE, J. A. \& BeLl, E. T. (1965) The effect of various compounds on pituitary function in man as judged by urinary gonadotrophin assays. Hormonal Steroids, vol. 2, p. 281. Eds. L. Martini and A. Pecile. Academic Press, New York.

Loraine, J. A. \& Beil, E. T. (1966) Hormone assays and their clinical application, 2nd edn, chap. 3. Livingstone, Edinburgh.

Loraine, J. A. \& Matthew, G. D. (1950) Chorionic gonadotrophin in toxaemias of pregnancy. $\mathcal{F}$. Obstet. Gynaec. Br. Emp. 57, 542.

Loraine, J. A. \& Matthew, G. D. (1954) Essais hormonaux dans la grossesse diabétique. Le Diabète, $2,43$.

McCarthy, C. \& Pennington, G. W. (1964) Maternal chorionic gonadotrophin concentration as an aid to the antenatal prediction of hemolytic disease of newborn infant. Am. 7. Obstet. Gynec. 89, 1069.

McGarthy, G., Pennington, G. W. \& Grawford, W. S. (1964) Chorionic gonadotrophin excretion in normal pregnancy. F. Obstet. Gynaec. Br. Commonw. 71, 86.

Mishell, D. R., Wide, L. \& Gemzell, C. A. (1963) Immunologic determination of human chorionic gonadotrophin in serum. F. clin. Endocr. Metab. 23, 125.

RILEY, G. M. (1959) Gynecologic endocrinology. Hoeber-Harper, New York.

SMrth, R. A. \& AlBert, A. (1955) Effects of oestrogen on urinary gonadotrophin. Proc. Staff Meet. Mayo Clin. 30, 617.

Thorborg, J. V. \& Hansen, K. (1951) The use of Xenopus laevis, Bufo bufo, and Rana esculenta as test animals for gonadotrophic hormones. III. Quantitative investigations on the sensitivity of animals to chorionic gonadotrophin. Acta endocr., Copenh. 6, 51.

Twomвly, G. H. (1944) The relationship of hormones to testicular tumors. Surgery, 16, 181.

WhITe, P. (1952) Pregnancy complicating diabetes. Treatment of Diabetes Mellitus, 9th edn, p. 676. Eds. E. P. Joslin, H. F. Root, P. White and A. Marble. Kimpton, London.

White, P. \& Hunt, H. (1943) Pregnancy complicating diabetes; a report of clinical results. 7 . clin. Endocr. Metab. 3, 500.

WIDE, L. (1962) An immunological method for the assay of human chorionic gonadotrophin. Acta endocr., Copenh. Suppl. 70.

Wide, L. \& Gemzeli, C. A. (1960) An immunological pregnancy test. Acta endocr., Copenh. 35, 261.

WILDE, C. E., ORR, A. H. \& BAgshawe, K. D. (1965) A radioimmunoassay for human chorionic gonadotrophin. Nature, Lond. 205, 191.

Zilliacus, H., Widholm, O. \& Pesonen, S. (1954) The concentration of chorionic gonadotrophin in the urine and in the placenta of Rh negative immunized mothers. Acta endocr., Copenh. 16, 343.

Zondek, B., Sulman, F. \& BlACK, R. (1945) Hyperemia effect of gonadotrophins on ovary and its use in rapid pregnancy test. F. Am. med. Ass. 128, 939.

ZoNDEk, L. H. \& ZONDEK, T. (1965) Leydig cells of the fetus and newborn in normal and toxaemic pregnancy. Biologia neonat. 8, 1. 